\title{
An Evaluation of the Autopsy Cases of Carbon Monoxide Poisoning in Trabzon Between 2009-2016
}

\author{
Trabzon'da 2009-2016 Y1llar1 Arasında Otopsisi Yapılan Karbon Monoksit \\ Zehirlenmelerinin Değerlendirilmesi
}

\author{
Hüseyin Çetin Ketenci ${ }^{1}$, Hülya Karadeniz ${ }^{2}$, Halil Boz ${ }^{1}$, Nazım Ercüment Beyhun ${ }^{3}$ \\ ${ }^{1}$ Trabzon Branch of the Council of Forensic Medicine, Trabzon \\ ${ }^{2}$ Karadeniz Technical University, Institute of Forensic Science, Trabzon \\ ${ }^{3}$ Karadeniz Technical University, Faculty of Medicine, Department of Public Health, Trabzon
}

\begin{abstract}
Objective: Carbon monoxide related deaths, which are generally preventable accidents, and more common when compared with other toxic substance consumption, arouse public attention in our country.

Materials and Methods: In this study, the aim is to investigate different features of carbon monoxide poisoning related deaths autopsied in Trabzon in 8-year period of time and demonstrate medico-legal aspects of this issue.

Results: Our study consists of all deaths due to carbon monoxide poisoning and autopsied by Trabzon Morgue Department of the Council of Forensic Medicine of Turkey between 2009 and 2016. Records of a total of 7133 criminal cases who were autopsied between these years were examined and 215 cases who died due to $\mathrm{CO}$ poisoning were evaluated for age, sex, the month of the event occurred, origin, death time, $\mathrm{CO}$ source and carboxyhemoglobin $(\mathrm{COHb})$ values. 215 criminal cases were constituting $3.01 \%$ of 7133 criminal cases who were autopsied within 8 years in Trabzon. 91 of the cases were $(42.3 \%)$ female and 124 were $(57.7 \%)$ male and the male/female case ratio was 1.4. Mean age of the cases was $48.8 \pm 27.1$ years. $24.1 \%$ of deaths occurred in January, $74 \%$ at home. $\mathrm{CO}$ source was found to be charcoal in $55.3 \%$ of cases. Mean $\mathrm{COHb}$ level detected in cases was $54.9 \pm 17.6 \%$.

Conclusion: Carbon monoxide poisoning is an important social problem in our country as in many developing countries. It is concluded that with their medicolegal experiences and suggestions, forensic medicine specialists can play an important role to manage carbon monoxide poisonings which are mainly preventable accidents and to help to increase social consciousness for carbon monoxide poisoning.
\end{abstract}

Keywords: Carbon Monoxide; Autopsy; Poisoning; Toxicology.

Corresponding Author: Assoc. Prof. Hülya Karadeniz

Karadeniz Technical University, Institute of Forensic Science, Trabzon Email: gulsu@ktu.edu.tr

Received: 17.05.2018 Revised: 30.05.2018 Accepted: 13.06.2018

\section{Özet}

Amaç: Ülkemizde karbonmonoksit (CO) zehirlenmesine bağl1 ölümlerin çoğunlukla önlenebilir kazalar şeklinde olması ve diğer toksik madde alımına bağlı ölümlere nazaran daha sık görülmesi, konunun gündemde kalmasını sağlamaktadır.

Gereç ve Yöntem: $\mathrm{Bu}$ çalışmada 8 yıllık süre içerisinde Trabzon'da otopsisi yapılan CO zehirlenmesine bağlı meydana gelen ölüm olgularının çeşitli yönlerden incelenmesi ve konunun adlitıbbi boyutunun ortaya konulması amaçlanmıştır.

Bulgular: Çalışmamız Adli Tıp Kurumu Trabzon Grup Başkanlı̆̆ı Morg ihtisas Dairesi'nde 2009-2016 yılları arasında otopsisi yapılan karbonmonoksit zehirlenmesine bağlı ölümlerin tamamını kapsamaktadır. Bu yıllar arasında otopsileri yapılan toplam 7133 adli olguya ait kayıtlar incelenmiş olup CO zehirlenmesi sonucu ölen 215 olgu yaş, cinsiyet, olayın meydana geldiği ay, orijin, ölüm süresi, CO kaynağı ve karboksihemoglobin $(\mathrm{COHb})$ değerleri açısından değerlendirilmiştir. 215 adli olgu Trabzon'da 8 y1lda otopsisi yap1lan 7133 adli olgunun $\% 3.01$ >ini oluşturmaktadır. Olguların 91〉i (\%42.3) kadın, 124>ü (\%57.7) erkek, erkek/kadın oranı 1,4〉dür. Yaş ortalaması $48.8 \pm 27.1$ 'dir. Ölümlerin \%24,1 ocak ayında, \%74)ü evlerde gerçekleşmiştir. Olguların \%55.3>ünde CO kaynağ1 olarak soba kömürü bulunmuştur. Olgularda tespit edilen ortalama $\mathrm{COHb}$ düzeyi $\% 54.9 \pm 17.6$ 'dir.

Sonuç: CO zehirlenmeleri, birçok ülkede olduğu gibi ülkemizde de sosyal bir sorun oluşturmaktadır. Adli Tıp Uzmanlarının; büyük çoğunluğu önlenebilir kazalar olan CO zehirlenmelerinin adli-tıbbi boyutunun ortaya konulmasında ve kamuoyunun bu konu ile ilgili olarak bilinçlendirilmesinde önemli katkıları olacağı kanaatindeyiz.

Anahtar Kelimeler: Karbonmonoksit; Otopsi; Zehirlenme; Toksikoloji.

\section{Introduction}

Carbon monoxide (CO) is a product of the incomplete combustion of carbon compounds such as organic ma- 
terials and hydrocarbons. It is colorless, tasteless, odorless, non-irritant and not easily detected by an exposed person (1). $\mathrm{CO}$ is toxic because its binding affinity for hemoglobin is 200-250 times higher than oxygen. Exposure to $\mathrm{CO}$ can be extremely detrimental to human health, and exposure to higher concentrations can result in death. The most common cause of $\mathrm{CO}$ poisoning in humans is breathing industrial smoke, smoke from fires, or automobile exhaust fumes, which is commonly the result of burning coal or wood in enclosed and improperly ventilated spaces or using insufficiently vented gas water heaters. Carbon monoxide poisoning can be either intentional or accidental (2-4). Carbon monoxide intoxication is the most common type of poisoning in our country and worldwide. It is shown to be one of the most important causes of death in countries such as the United States, Great Britain, France, Morocco, South Korea, and Israel (5-7).

The aim of the present study was to retrospectively investigate the epidemiology and forensic aspects related to $\mathrm{CO}$ poisoning, in cases with postmortem $\mathrm{COHb}$ analysis, from autopsies performed at the Morgue Department of Trabzon Branch of the Council of Forensic Medicine, between the years 2009 and 2016 .

\section{Materials and Methods}

For this study, the autopsy records of the Morgue Department of the Trabzon Branch of the Council of Forensic Medicine in the period between January 2009 and December 2016 were reviewed. A total of 7133 autopsies had been performed and $215(3.01 \%)$ of these involved $\mathrm{CO}$ poisoning. The cases were evaluated according to the following criteria: age, gender, year, month, season of death, occupation, source of $\mathrm{CO}$, origin, location of exposure to CO, autopsy findings (lividity, lesions, coloration of blood and internal organs) and toxicological analysis results. The Statistical Package for Social Sciences (SPSS) version 13 was used in data analysis.

Table 1. Number of cases per year

\begin{tabular}{|c|c|c|}
\hline Year & $\mathbf{n}$ & $\mathbf{\%}$ \\
\hline 2009 & 23 & 10.7 \\
\hline 2010 & 23 & 10.7 \\
\hline 2011 & 37 & 17.2 \\
\hline 2012 & 42 & 19.5 \\
\hline 2013 & 24 & 11.2 \\
\hline 2014 & 30 & 14.0 \\
\hline 2015 & 23 & 10.7 \\
\hline 2016 & 13 & 6.0 \\
\hline
\end{tabular}

\section{Results}

From January 2009 to December 2016, a total of 7133 autopsies were performed; 215 (3.01\%) of them were related to $\mathrm{CO}$ poisoning. The number of cases per year is presented in Table 1 .

The mean age was $48.8 \pm 27.1$ years and the youngest and the oldest cases were 1 and 98 years of age, respectively. Males were involved in $57.7 \%(n=124)$ of the cases and the mean age of male cases was $47.7 \pm 26.6$ years, and females were involved in $42.3 \%(n=91)$ of them and the mean age of female cases was $50.2 \pm 27.9$ years. The male to female ratio was 1.4. The highest frequency of $\mathrm{CO}$ deaths was found in the $>70$ years age group ( $\mathrm{n}=59,27.44 \%)$ (Fig. 1).

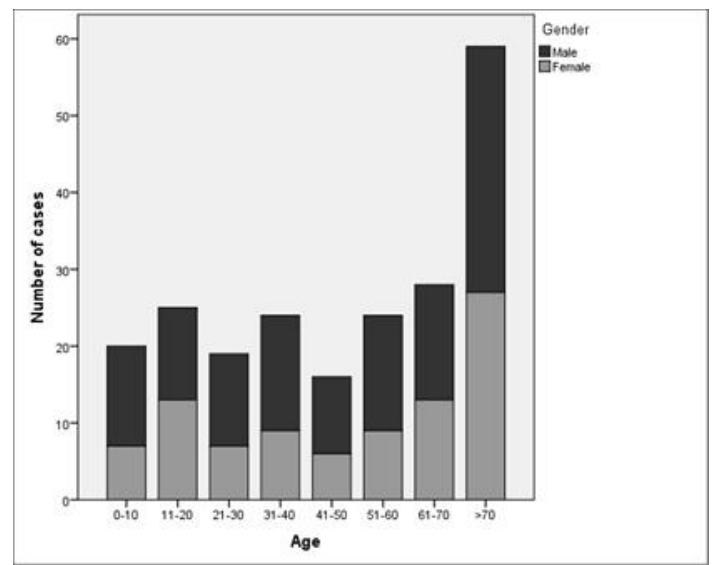

Figure 1. Age and gender distribution of $\mathrm{CO}$ poisoning.

The number of CO deaths was highest in 2012 with 42 cases (19.53\%), followed by 2011 with 37 cases (17.21\%). The lowest number of deaths occurred in 2016 with 13 cases $(6.05 \%)$ (Fig.2).

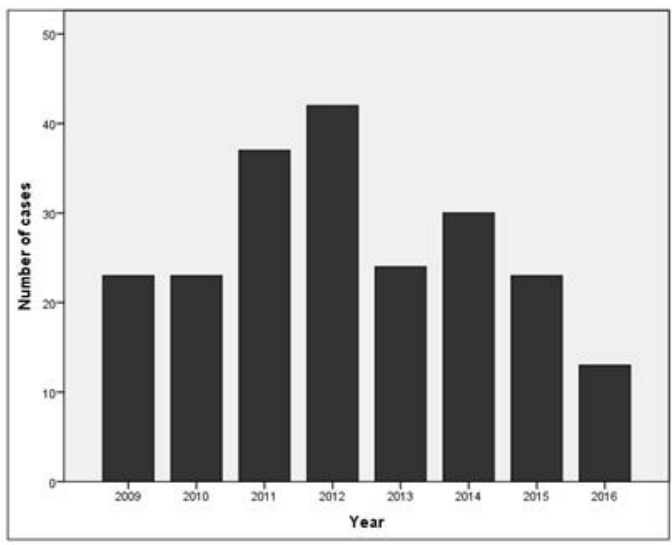

Figure 2. CO poisoning deaths according to the years.

The highest number of $\mathrm{CO}$ poisoning related deaths occurred in January (52 cases, 24.18\%) and the lowest in July, August and October (Fig. 3) 


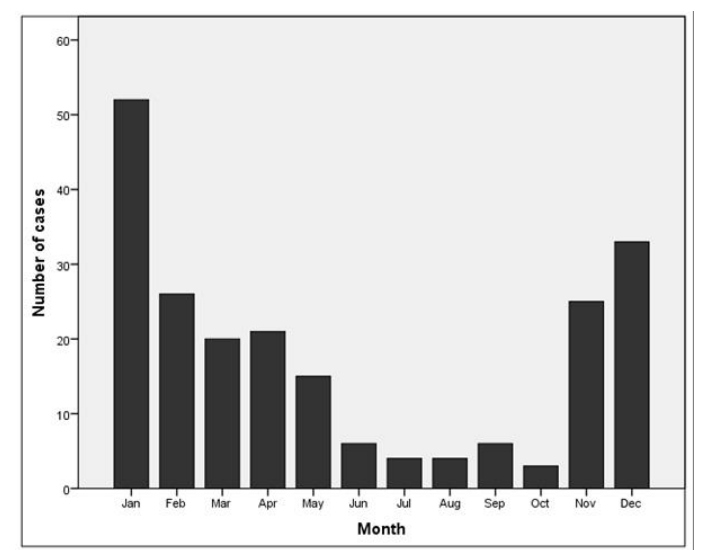

Figure 3. CO poisoning related deaths according to months.

The sources of $\mathrm{CO}$ were as follows: coal stoves $(\mathrm{n}=$ 119; $55.3 \%)$; fires $(\mathrm{n}=44 ; 20.5 \%)$; water heaters in baths $(\mathrm{n}=31 ; 14.4 \%)$, auto exhaust fumes $(\mathrm{n}=3,1.4 \%)$. In 18 cases $(8.4 \%)$ there was no source of $\mathrm{CO}$ at the death scene. The origins of $\mathrm{CO}$ poisoning were as follows: unintentional $(\mathrm{n}=213 ; 99.0 \%)$, homicide $(\mathrm{n}=1 ; 0.5 \%)$ and suicide $(\mathrm{n}=1$, $0.5 \%$ ). Most of the cases of CO poisoning occured in the night ( $\mathrm{n}=127,59.1 \%)$. In addition, most of the cases of $\mathrm{CO}$ poisoning occurred at home and in the bathroom (Table 2). Furthermore; the cases of $\mathrm{CO}$ poisoning occured in urban areas $(n=117,54.4 \%)$ rather than rural area $(n=98,45.6 \%)$.

Table 2. The locations where CO poisoning events occurred

\begin{tabular}{|l|c|c|}
\hline Place & $\mathbf{n}$ & $\mathbf{\%}$ \\
\hline Home & 159 & 74.0 \\
\hline Bathroom & 30 & 14.0 \\
\hline In vehicle & 6 & 2.8 \\
\hline Hotel room & 4 & 1.9 \\
\hline Hut & 4 & 1.9 \\
\hline Workplace & 3 & 1.4 \\
\hline Tandoor well & 2 & 0.9 \\
\hline Water well & 1 & 0.5 \\
\hline Basement & 1 & 0.5 \\
\hline Tunnel construction & 1 & 0.5 \\
\hline Public bath & 1 & 0.5 \\
\hline Hayloft & 1 & 0.5 \\
\hline Mountain house & 1 & 0.5 \\
\hline Total & $\mathbf{2 1 5}$ & $\mathbf{1 0 0 . 0}$ \\
\hline
\end{tabular}

According to toxicological analysis results, the mean $\mathrm{COHb} \%$ in individuals with a $\mathrm{COHb}$ level who died due to $\mathrm{CO}$ poisoning was $54.9 \pm 17.6 \%$, and the lowest and highest levels of $\mathrm{COHb}$ were $5 \%$ and $86 \%$, respectively. The levels of carboxyhemoglobin in the blood are shown in Figure 4.

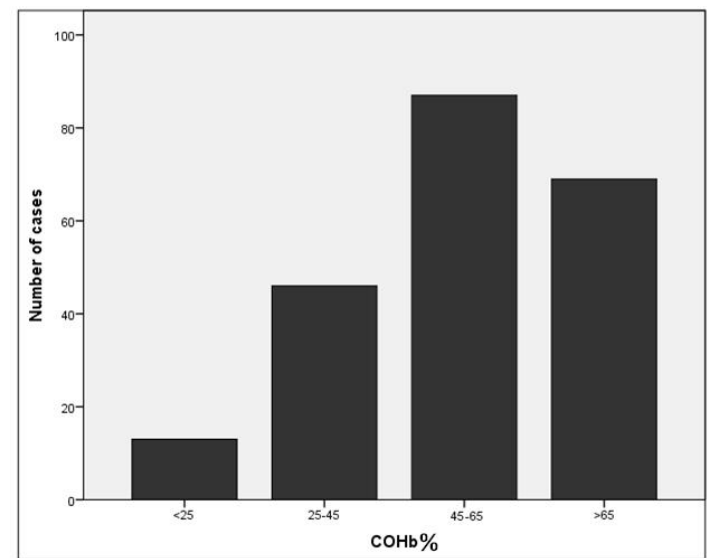

Figure 4. The level of $\mathrm{COHb}$ in blood.

We were able to detect alcohol in 10 cases (4.7\%), and the lowest and highest blood alcohol level were $53 \mathrm{mg} / \mathrm{dl}$ and $577 \mathrm{mg} / \mathrm{dl}$, respectively. Illegal drugs were found in 4 cases $(1.8 \%)$. Marijuana was detected in 2 cases $(0.9 \%)$, marijuana together with benzodiazepine in one case, and morphine in one case. Prescription drugs were found in 8 cases $(3.7 \%)$. These prescription drugs were antidepressants and benzodiazepines. Antidepressants were found in 5 cases $(2.32 \%)$, and antidepressants together with benzodiazepine in 3 cases (1.4\%). In 192 cases (89.3\%) alcohol and drugs couldn't be detected.

In $167(77,7 \%)$ of the cases light red/pinkish death marks, in 45 of them macroscopically distinguishable dermal burns, in $31(14,4 \%)$ soot-smoke smears on the surface of the skin, in $21(9,7 \%)$ foam in/around the mouth and nostrils, in $5(2,3 \%)$ superficial blunt trauma and in another 1 blunt trauma causing broken bones were determined in the external examinations. Decay signs were determined in the external examination of $2(0.9 \%)$ cases.

In the internal examination intense hyperemia in internal organs and edema in parenchymal tissues was detected in $173(80,5 \%)$ of the cases. In 39 cases $(18,1 \%)$ the weight of each lung was more than 750 grams. In 36 $(16,7 \%)$ cases there were soot and smoke smears in the upper and lower respiratory tracts, in $33(15,3 \%)$ cases intense punctual bleeding in the mucosa and serosa and in $38(17,7 \%)$ cases there were 4 th degree burns causing carbonization in the internal organs.

\section{Discussion}

During the period between 2009 and 2016, the ratio of deaths due to $\mathrm{CO}$ poisoning in autopsied deaths in Trabzon was detected as $3.01 \%(n=215)$. The percent- 
age of $\mathrm{CO}$ poisoning cases compared to the total number of autopsies performed was 3.8\% in Bursa (8), $2.7 \%$ in İstanbul (9), 3.85\% in Ankara (10), $1.28 \%$ in Aydın (11) and $1.99 \%$ in Adana (12). The deaths as a result of CO poisoning differ from region to region in Turkey. The climate characteristics and economical and social structures of the region affect the frequency of carbon monoxide poisoning cases. In the cities mentioned above, the winter months are hotter in Adana and Aydın. In the other cities, the winter months are colder in Bursa, İstanbul and Ankara. The coldest winter months are seen in Trabzon. Consequently, cold weather increases the usage of coal stoves and water heaters that are $\mathrm{CO}$ sources that increase the death rates. According to the other studies in different countries, Ait el Cadi et al. reported the rate of $\mathrm{CO}$ poisoning in autopsied deaths as $3.15 \%$ in Morocco (5), Nazari et al. found this ratio as $11.6 \%$ in Iran between the years 2003 and 2008 (13), and Liu et al. reported this ratio as $16.5 \%$ in China between the years 1999 and 2008 (14).

The mean age of the cases in this study was $48.8 \pm 27.1$ while it was $36.6 \pm 21.9$ years in Istanbul (15), $40.3 \pm 21.8$ years in Ankara (10), 60.3 \pm 23.4 years in Aydın (11), 46.8 years in Bursa (8), 34 years in Morocco (5) and $42 \pm 26$ years in Portugal (16). In this study, the youngest and oldest cases were 0 and 98 years of age. The age of the cases ranged between 8 months and 98 years in Istanbul (15), 0-97 years in Adana (12) and 15-82 years in Edirne (17).

Most of the cases were observed in winter $(72.55 \%)$ and in January (24.18\%) and the lowest number was observed in summer $(6.51 \%)$. Similar studies report that cases of death due to $\mathrm{CO}$ poisoning were most frequently encountered during winter $(5,8,13,15-19)$.

In this study, all $\mathrm{CO}$ poisoning deaths were unintentional in manner. There were one homicide case and one suicide case. It was determined that a murder and a suicide determined in our study occurred during the same case from the legal documents which were drafted. The documents put forward that after injuring her mother with a shotgun, a female case burnt the house they were in and that both of them died in this fire. Since murder and suicide are rarely found together in cases related to carbon monoxide poisoning, these two cases were found to be extraordinary. In the other study; the frequency of accidental cases of $\mathrm{CO}$ poisoning in Morocco, Ankara, İzmir and Cleveland, Ohio in the United States were 93.5\%, $98.3 \%, 91 \%$ and $69.0 \%$, respectively $(5,10,18,20)$. Furthermore; there has been a recent increase in suicide related $\mathrm{CO}$ poisoning. For example, there has been an increase in Taiwan in the annual number of deaths due to $\mathrm{CO}$ poisoning over the past 10 years, which may be associated with the increase in the number of suicides committed by inhaling the fumes of burning charcoal $(21,22)$. The burning of charcoal in enclosed spaces has been described as a particular method of suicide used by the Chinese, and it has rapidly increased as a method used in South Korea $(23,24)$.

The $\mathrm{CO}$ poisonings were attributed to coal stoves for heating purposes $(55.3 \%)$, water heaters used in shower systems $(14.4 \%)$, house or building fires $(20.5 \%)$, and exhaust gases of automobiles (1.4\%). In a study conducted by Türkmen et al, the frequency of the causes of CO poisoning cases in Bursa were $48.5 \%$ for coal stoves and $28.3 \%$ for gas water heaters (19). The most common causes of CO poisoning in Ankara were coal stoves, gas water heaters, and fires. Furthermore; using a barbecue for cooking in an enclosed space caused $3.4 \%$ of $\mathrm{CO}$ poisoning cases, $2.3 \%$ were caused by exhaust gases, and one was caused by an explosion in a mine (10). CO poisoning accounted for $2.5 \%$ of the cases of fire-related deaths in Istanbul. Among the 33 cases included in the present study, the source of CO was fire for $23(69.7 \%)$ and stoves for nine $(27.3 \%)$ cases. One $(3 \%)$ of the cases was an individual who committed suicide by inhaling bottled gas through a hose that he had inserted into his mouth (15). CO poisoning in the Aydın province occurred more frequently in association with fires. The absence of $\mathrm{CO}$ poisoning cases due to gas water heaters in Aydin can be attributed to the prevalent use of solar energy water heaters throughout much of the year (11).

In this study, the most common setting of $\mathrm{CO}$ poisoning was at home $(74.0 \%)$. In other provinces in Turkey, for example, in Ankara, $90.8 \%$ of cases died in their homes (10). CO poisoning caused $15.4 \%$ of the deaths in bathrooms in Diyarbakır (25). In Bursa and Diyarbakır, $79.8 \%$ and $15.4 \%$ of $\mathrm{CO}$ poisoning cases occurred at homes and in bathrooms, respectively $(19,25)$

In the present study, the lowest and highest levels of carboxyhemoglobin content in the blood were $5 \%$ and $85 \%$, respectively. The case whose carboxyhemoglobin was $5 \%$, the woman case who was 63 years old and thought to be poisoned by the gas water heater while washing at home, was found unconscious in the bathroom and taken to the hospital in the same day. Because of the hyperbaric oxygen and intensive liquid replacement applied to her during her 1 day treatment in the coronary intensive care unit, the $\mathrm{COHb}$ measurement couldn't be made in the blood taken just before the first intervention. Therefore; the ratio of $\mathrm{COHb}$ at the moment of poisoning cannot be detected. The level of $\mathrm{COHb}$ was measured as $5 \%$ in postmortem blood. It is thought that this figure is related to the treatment which was applied. The prevalent ranges of carboxyhemoglobin levels observed in Istan- 
bul, Ankara, Aydın and Bursa were 11-50\%, 22.2-80.2\%, $1.9-79.7 \%$ and $31-50 \%$ respectively $(9,10,11,19)$.

In our study, routine toxicological analysis was carried out in all cases and alcohol was detected in $4.7 \%$ of the cases. Illicit drugs were detected in 4 cases (marijuana in 3 cases, morphine in one case), and prescription drugs were found in 8 cases (antidepressants in 5 cases, antidepressants together with benzodiazepine in 3 cases). In a study conducted by Cantürk et al., alcohol was detected in the blood of $26.9 \%$ of the cases. The highest level of alcohol in the blood was $318 \mathrm{mg} / \mathrm{dl}$ (10). In a study conducted by Ruas et al. blood alcohol, prescription and illicit drug analyses were negative in all the $\mathrm{CO}$ intoxication cases (16). In fact, the substances have been related to an increased risk of $\mathrm{CO}$ related accidents, and to the ingestion of large quantities of drugs before CO-related suicide attempts $(20,26)$, even though a study reported that the presence of drugs did not change the cause of death (20).

Light red/pinkish death marks which are one of the distinguishing external examination findings in $\mathrm{CO}$ poisoning were detected in three-quarters of the cases. The level of $\mathrm{COHb}$ was measured to be under $45 \%$ in 58 of the cases. The reason why characteristic death marks were not found elderly cases is believed to be that the $\mathrm{COHb}$ levels were low. In addition, the existence of some cardiac or hematological diseases about which data couldn't be collected within the scope of the study may have prevented the formation of lightly colored death marks. It was found that the formation of dermal burns in cases that died by being poisoned in a fire is compatible with the literature $(15,16,26-28)$. Foam can be observed around the mouth and nose in CO poisoning. This was detected in 21 of the cases. Wooden roofs or heavy and stiff objects in the area where the fire takes place may fall on people either when they are alive or dead. Just as they may cause secondary trauma before death they may also cause the formation of postmortem artefacts. Within this scope superficial blunt trauma not causing breaks in bones was detected in 5 cases. In 1 case it was detected that the bone was broken in the postmortem period.

In $80.5 \%$ (n: 173) of the cases the common and intense hyperemia and edema found in the internal organs, serosas and mucosal tissues were compatible with $\mathrm{CO}$ poisoning findings. In addition, the intense punctual bleeding observed in $15.3 \%$ ( $\mathrm{n}: 33$ ) of the cases as a result of asphyxia just like hyperemia and edema. The edema resulting from the effect of $\mathrm{CO}$ poisoning causes dramatical changes especially in the parenchyma of the lungs. Another reason of weight increase of the lungs is intraalveolar bleeding. In $18.1 \%$ (n: 39 ) of our cases both of the lungs weigh more than 750 grams. This weight in- crease was found to be compatible with lung edema. Carbon monoxide is a poisonous gas which appears in the smoke forming as a result of the incomplete combustion of fuels containing carbon. This smoke accumulates in the lower and upper respiratory tracts of people whose respiration continue. In $16.7 \%$ (n: 36 ) of the cases there were macroscopically observable soot and smoke smears in the larynx, trachea and bronchus. When this finding is distinguishable especially in the lower respiratory tract it shows that the person was alive for some time in the smoke. It also incorporates hypoxic hypoxia into the causes of death in addition to the effects of $\mathrm{CO}$. The internal organ burns detected in $17.7 \%$ (n: 38 ) of the cases are of 4 th degree. The heat reaches the internal organs via the disintegrated burnt skin and causes carbonization. This can continue during the postmortem period. In compliance with external examination putrefaction and autolytic changes were detected in the internal organs of $0.9 \%$ (n: 2 ) of the cases. These findings indicate a natural process which occurs as a result of the prolongation of the postmortem interval in corpses. The death times of these 2 cases are not certain and it is thought that about 48 hours passed since their deaths.

\section{Conclusion}

$\mathrm{CO}$ poisoning has been accepted to be one of the leading significant health problems. Accidental CO poisoning is a preventable condition. The community should be educated by governmental organizations, non-governmental organizations, schools, and private initiatives related to the dangers of heating living places with charcoal, gaseous and liquid fuels without the appropriate ventilation. Residential CO sensors should be made use of for the early detection of abnormal $\mathrm{CO}$ levels.

\section{References}

1. Prakash A, Agarwal SK, Prakash N. Carbon Monoxide Poisoning. Apollo Med. 2010;7:32-34. DOI: https://doi. org/10.1016/S0976-0016(12)60004-0

2. Iheagwara KN, Thom SR, Deutschman CS, Levy RJ. Myocardial Cytochrome Oxidase Activity is Decreased Following Carbon Monoxide Exposure. Biochim Biophys Acta 2007;1772(9):1112-6. DOI: https://doi.org/10.1016/j.bbadis. 2007.06 .002

3. Gorman D, Drewry A, Huang YL, Sames C. The Clinical Toxicology of Carbon Monoxide. Toxicology 2003;187:2538. DOI: https://doi.org/10.1016/S0300-483X(03)00005-2

4. Kao LW, Nanagas KA. Carbon Monoxide Poisoning. Med Clin North Am. 2005;89(6):1161- 94. DOI: https://doi. org/10.1016/j.mcna.2005.06.007

5. Ait El Cadi M, Khabbal Y, Idrissi L. Carbon Monoxide Poisoning in Morocco During 1999-2007. J Forensic 
Leg. Med. 2009;16:385-7. DOI: https://doi.org/10.1016/j. jflm.2009.01.017

6. Metin S, Yıldız Ş, Çakmak T, Demirbaş Ş. Frequency of Carbon Monoxide Poisoning in Turkey in 2010. TAF Prev Med Bull. 2011; 10(5):587-92. DOI: https://doi.org/10.5455/ pmb.20110417125648

7. Raub JA, NolfMM, Hampson NB, Thom SR. Carbon Monoxide Poisoning a Public Health Perspective. Toxicology 2000;145:1-14. DOI: https://doi.org/10.1016/S0300483X(99)00217-6

8. Eren F, Gürses MS, Ural MN, İnanır NT, Eren B, VojtisekT. Carbonmonoxide Poisoning Cases Autopsied in South Marmara Region, The Bulletin of Legal Medicine 2014;19(2):96-99. DOI: https://doi.org/10.17986/ blm.2014192755

9. Berber G, Üzün İ, Ak N. Evaluation of Carbon Monoxide Poisoning From The Morgue Department of Council of Forensic Medicine Between The Years 1995-1998. Forensic Medicine Annual Meeting Book, 16-19 May 2002, Antalya, Turkey.

10. Cantürk N, Basbulut AZ, Cantürk G, Dagalp R. Evaluation of The Autopsy Cases Carbon Monoxide Poisonings in Ankara Between 2002-2006. J Forensic Med. 2008;22:25-30.

11. Dirlik M, Bostancıoğlu B. Deaths Due To Carbon Monoxide Poisoning in Aydın, Western Turkey. Death Studies 2017;41(4):246-50. DOI: https://doi.org/10.1080/07481187 .2016 .1259693

12. Battal D, Aktas A, Sungur MA, Bilgin NG, Cekin N. Evaluation of Poisoning Deaths In The Cukurova Region, Turkey, 2007-2011.Toxicol Ind Health. 2016;32(3):476-84. DOI: https://doi.org/10.1177/0748233713503376

13. Nazari J, Dianat I, Stedmon A. Unintentional Carbon Monoxide Poisoning in Northwest Iran: A 5-year study.J Forensic Leg. Med. 2010;17:388-39. DOI: https://doi.org/10.1016/j. jflm.2010.08.003

14. Liu Q, Zhou L, Zheng N, Zhuo L, Liu Y, Liu L.Poisoning Deaths In China: Type and Prevalence Detected At The Tongji Forensic Medical Center in Hubei. Forensic Sci Int. 2009;193:88-94. DOI: https://doi.org/10.1016/j.forsciint.2009.09.013

15. Buyuk Y, Kocak U. Fire-related fatalities in Istanbul, Turkey: Analysis of 320 Forensic Autopsy Cases. J Forensic Leg Med 2009;16:449-54.DOI: https://doi.org/10.1016/j. jflm.2009.05.005

16. Ruas F, Mendonça MC, Real FC, Vieira DN, Teixeira HM.Carbon Monoxide Poisoning As a Cause of Death and Differential Diagnosis in The Forensic Practice: A Retrospective Study, 2000-2010. J Forensic Leg. Med, 2014;24:16. DOI: https://doi.org/10.1016/j.jflm.2014.02.002
17. Azmak D. Asphyxial deaths: A Retrospective Study And Review of The Literature. Am J Forensic Med Pathol 2006; 2: 134-144. DOI: https://doi.org/10.1097/01. paf.0000221082.72186.2e

18. Erturk S, Hancı IH, Koçak A, Aktas EO. Deaths Due to Poisoning Among Forensic Autopsies in Izmir Between 19901994. Ege J Med. 2001;40:117-9.

19. Türkmen N, Akgöz S. Deaths Due to Carbon Monoxide Poisonings Autopsied in Bursa. J Forensic Med, 2005;19(2):20-25.

20. Przepyszny L, Jenkins A. The Prevalence of Drugs in Carbon Monoxide-Related Deaths: A Retrospective Study, 2000-2003. Am J Forensic Med Pathol 2007;28:242-8. DOI: https://doi.org/10.1097/01.paf.0000257417.26383.e4

21. Liu KY, Beautrais A, Caine E, Chan K, Chao A,Conwell Y, LawC, Lee D, Li P,Yip P. Charcoal Burning Suicidesin Hong Kong and Urban Taiwan: An Illustration of Theimpact of A Novel Suicide Method on Overall Regional Rates.J Epidemiol Community Health. 2007;61(3):248-53. DOI: https://doi.org/10.1136/jech.2006.048553

22. Shie HG, Li CY. Population-Based Case-Control Study of Risk Factors for Unintentional Mortality From Carbon Monoxide Poisoning in Taiwan. Inhal Toxicol. 2007;19(10),90512. DOI: https://doi.org/10.1080/08958370701432173

23. Choi YR, Cha ES, Chang SS, Khang YH, Lee WJ. Suicide From Carbon Monoxide Poisoning in South Korea: 20062012. J Affect Disord. 2014;167:322-5. DOI: https://doi. org/10.1016/j.jad.2014.06.026

24. Lee AC, Ou Y, Lam SY, So KT, Kam CW. Non-Accidental Carbon Monoxide Poisoning From Burning Charcoal in Attempted Combined Homicide-Suicide. J Paediatr Child Health.2002;38(5):465-8. DOI: https://doi.org/10.1046/ j.1440-1754.2002.00019.x

25. Gören S, Tıraşçı Y, Üzün İ. The Retrospective Evaluation of Deaths In Bathroom. J Forensic Med. 2005;19(1):29-32. DOI: https://doi.org/10.1016/j.jflm.2012.04.031

26. Popovic V, Atanasijevic T, Nikolic S, Micic J. Concentration of Carbon-Monoxide in Carbonized Bodies Forensic Aspects. Leg Med 2009;11:318-20. DOI: https://doi. org/10.1016/j.legalmed.2009.01.045

27. Karapirli M, Kandemir E, AkyolS, Kantarci MN, Kaya M, Akyol O. Forensic and Clinical Carbon Monoxide (CO) Poisonings in Turkey: A Detailed Analysis. J Forensic Leg. Med. 2013;20:95-101. DOI: https://doi.org/10.1016/j. jflm.2012.04.031

28. Risser D, Schneider B. Should Coroners Be Able to Recognize Unintentional Carbon Monoxide-Related Deaths Immediately at The Death Scene? J Forensic Sci 1995;40(4):5968. DOI: https://doi.org/10.1520/JFS13832J. 